\title{
Stable isotope composition and turnover of nitrate in the German Bight
}

\author{
Kirstin Dähnke ${ }^{1,2,3, *}$, Kay Emeis ${ }^{1,2}$, Astrid Johannsen ${ }^{1,2}$, Birgit Nagel ${ }^{1,2}$ \\ ${ }^{1}$ GKSS Research Centre, 21502 Geesthacht, Germany \\ ${ }^{2}$ IfBM, University of Hamburg, 20146 Hamburg, Germany \\ ${ }^{3}$ Present address: Institute of Biology, University of Southern Denmark, 5230 Odense M, Denmark
}

\begin{abstract}
The German Bight is a hot-spot of eutrophication in the North Sea due to nitrate loads discharged by several large rivers into this semi-isolated embayment. River nitrate loads have a distinctly higher ${ }^{15} \mathrm{~N} /{ }^{14} \mathrm{~N}$ ratio than nitrate in open North Sea waters, and to trace the sphere of river influence we analysed stable isotope signatures of water column nitrate in the area on a grid of stations in winter and early spring 2007. Overall spatial patterns of ${ }^{15} \mathrm{~N} /{ }^{14} \mathrm{~N}$ and ${ }^{18} \mathrm{O} /{ }^{16} \mathrm{O}$ in nitrate reflect the predominant influence of nitrate discharged by the Rhine and Elbe rivers on the German Bight nitrate pool. On a smaller scale, however, and in offshore stations, nitrate assimilation of an incipient phytoplankton bloom is indicated by parallel enrichment of ${ }^{15} \mathrm{~N}$ and ${ }^{18} \mathrm{O}$ in nitrate. Intriguingly, the enrichment ratio of ${ }^{18} \mathrm{O}_{\mathrm{NO} 3}$ to ${ }^{15} \mathrm{~N}_{\mathrm{NO} 3}$ is 1.6:1, thus differing from the ratio of 1:1 associated with uptake by marine phytoplankton. This suggests that nitrate isotopic composition is not solely affected by phytoplankton assimilation, but that a substantial portion of nitrate in the outer regions of the German Bight is derived from nitrification, despite low ambient temperatures. Moreover, the data identify remineralisation and nitrification of particulate $\mathrm{N}$ in sediments as important sources of dissolved inorganic nitrogen to the German Bight water column, and underscore the role of sediments in recharging water column nutrient inventories.
\end{abstract}

KEY WORDS: Nitrogen cycle $\cdot \delta^{15} \mathrm{~N} \cdot \delta^{18} \mathrm{O} \cdot$ Stable isotopes $\cdot$ German Bight $\cdot$ Nitrification

\section{INTRODUCTION}

The German Bight/south-eastern North Sea is a shallow shelf sea (40 m on average; Fig. 1) with a predominant counter-clockwise circulation pattern. A mixture of Atlantic water and continental discharge (the Continental Coastal Water [CCW] with salinity $<33$ ) enters from the east and is transported along the Dutch and German coast to the north. As in many coastal water bodies, the nutrient budget of the German Bight/SE North Sea is inflated by anthropogenic inputs of inorganic nitrogen, causing eutrophication with negative consequences for the ecosystem (Cloern 2001). In the German Bight, these include enhanced phytoplankton blooms, hypoxia in bottom waters and changes in the dissolved nutrient ratios, which may have led to changes in species composition (van Beusekom 2005).

Sources of water column nitrate are: (1) anthropogenic nitrate loads, which derive from the densely populated adjacent land and reach the German Bight via atmospheric deposition or riverine input (Beddig et al. 1997, Brion et al. 2004); (2) recycled nitrate from mineralised of organic matter in sediments or suspended matter within in the German Bight (Hydes et al. 1999); and (3) advective fluxes with waters flowing in from the open North Sea (Central North Sea Water [CNSW], salinity >34.5). The best-quantified sources are anthropogenic inputs via the atmosphere $(29 \mathrm{kt} \mathrm{N}$ $\mathrm{yr}^{-1}$ ) and rivers (256 kt N yr${ }^{-1}$ ) (Pätsch et al. 2010). In rivers, a slight downward trend in nitrate concentrations has been observed in recent years (Radach \& 


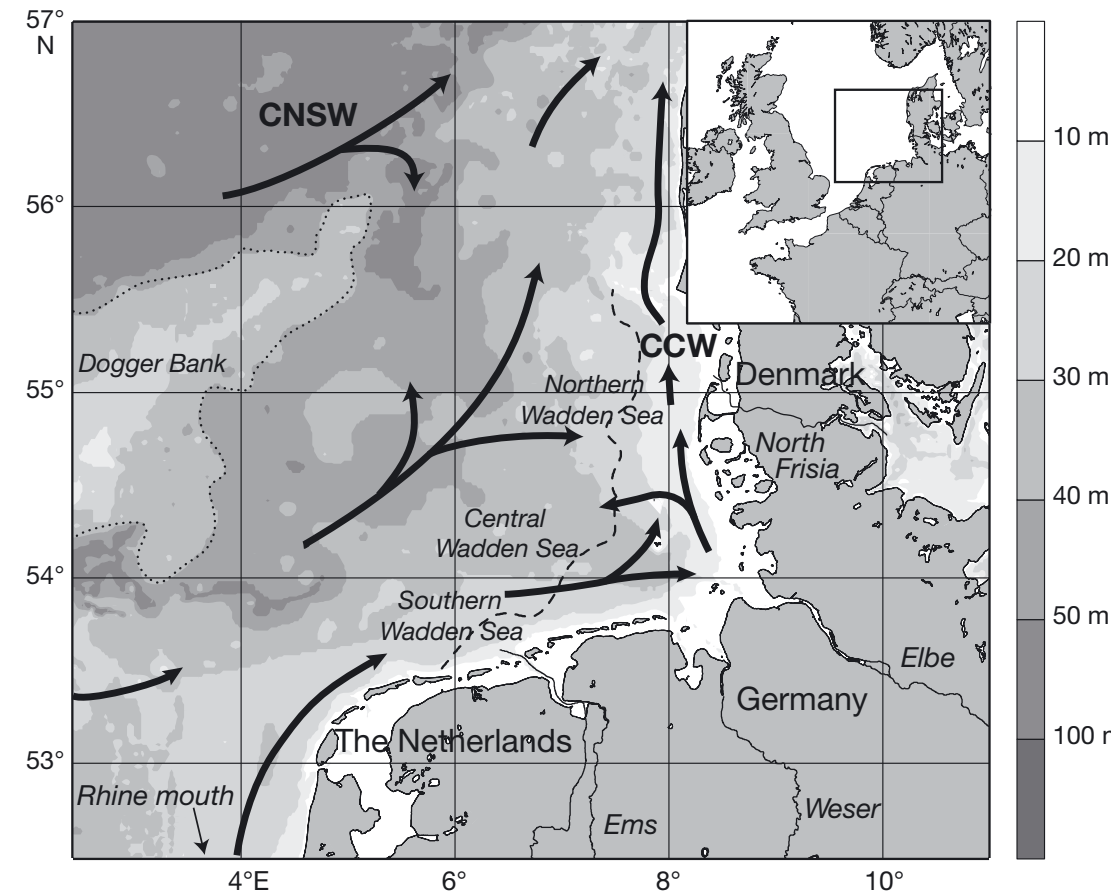

Fig. 1. German Bight. Nitrogen input pathways and overview of water currents. Grey scale denotes water depth (right bar). Dotted contours indicate the shallow Dogger Bank. Dashes: climatological salinity contour of 33, i.e. the border of the Continental Coastal Water mass (CCW). The Central North Sea Water (CNSW) is characterized by salinities $>34.5$

Pätsch 2007), but the reason for this trend is still unknown, and inputs of nitrate are still clearly elevated over pristine concentrations (van Beusekom 2005) and far above the desired threshold of the Water Framework Directive of the European Union. It is thus important to evaluate the poorly defined sources and sinks of nitrate, such as advective fluxes into and out of the German Bight via residual currents, phytoplankton uptake and exchang processes with sediments. Sediments -increasingly recognized as an important player in biogeochemical cycles of shallow seas (Soetaert \& Middelburg 2009) - may act as a nitrate sink due to denitrification, and they are also a site of active $\mathrm{N}$ recycling. As yet, the impact of recycled nitrate from ammonification/nitrification of suspended mater and of autochthonous particulate organic nitrogen (PON) is poorly constrained, but recycled nitrate may be equally important as 'new' anthropogenic inputs in fueling phytoplankton blooms that occur in spring and summer (Richardson et al. 2000). A previous estimate suggests that recycled nitrate can contribute up to $50 \%$ to $\mathrm{N}$-demand of phytoplankton assimilation in the German Bight (Lohse et al. 1993). Estimates for dissolved inorganic nitrogen (DIN) input by water masses advected into the bight range from $70 \%$ (Beddig et al. 1997 ) to $<10 \%$ (Hydes et al. 1999). More recent estimates with a coupled hydrodynamic and ecosystem model (Pätsch et al. 2010) suggest that internal turnover of reactive $\mathrm{N}$ in the German Bight exceeds imports and exports and that estimates for reactive nitrogen assimilation are not balanced by the modelled benthic remineralisation, requiring intense recycling of particulate $\mathrm{N}$, not only in surface sediment, but also in the water column.

To date, no attempt has been made to combine concentration-based estimates of nitrate sources and sinks with estimates based on the stable isotope composition of nitrate, which allows both source attribution and clarification of turnover and uptake processes in global and regional cycles of reactive nitrogen (e.g. Sigman et al. 2005, Wankel et al. 2006, Knapp et al. 2008, Bourbonnais et al. 2009). External nitrate inputs to the North Sea and the German Bight are distinct in their $\delta^{15} \mathrm{~N}$ ratio. $\delta^{15} \mathrm{~N}$ expresses the ratio of ${ }^{15} \mathrm{~N}$ to ${ }^{14} \mathrm{~N}$ in relation to that ratio $(R)$ in a standard: $\delta^{15} \mathrm{~N}_{\text {sample }}=\left(R_{\text {sam- }}\right.$ ple $\left./ R_{\text {standard }}-1\right) \times 1000$ in \%; the international standard being $\delta^{15} \mathrm{~N}$ air $\mathrm{N}_{2}=0 \%$. The $\delta^{15} \mathrm{~N}_{\mathrm{NO} 3}$ of inflowing water of Atlantic origin should, in winter, correspond to the nitrate in sub-thermocline waters of the Atlantic Ocean (4 to 5\%) (Bourbonnais et al. 2009). Rivers discharging into the SE North Sea, Rhine and Elbe, contribute an annual average $\delta^{15} \mathrm{~N}_{\mathrm{NO} 3}$ of $8 \%$ (Johannsen et al. 2008), and the $\delta^{15} \mathrm{~N}_{\mathrm{NO} 3}$ of atmospheric input is around 2.5\% (Freyer 1991).

So far research work on $\delta^{15} \mathrm{~N}$ in the German Bight has been concentrated only on particulate matter and surface sediments, which integrate effects of the isotope mixture of the water column nitrate inventory, diagenesis and sediment reworking (Pätsch et al. 2010). Average $\delta^{15} \mathrm{~N}_{\mathrm{NO} 3}$ values in surface sediments of the German Bight (6.8\%; Dähnke et al. 2008b) are elevated over the marine background of $5 \%$, and their spatial patterns lead to a first approximation of the influence of river nitrate composed of isotopically heavy DIN from urban or agricultural catchments (Johannsen et al. 2008).

In the present study we extended research perspectives from sedimentary PON to dissolved nitrate by analyzing the dual nitrate isotopes in water samples collected at stations in the German Bight and further offshore before and at the onset of a spring phytoplankton bloom in 2007. Our main goal was to use isotopic fingerprints to segregate nitrate-rich coastal waters from marine nitrate and to decide if isotope patterns indicate conservative mixing of the 2 pools, or 
if non-conservative mixing points towards nitrate turnover within the bight. We found evidence for a significant contribution of recycled benthic nitrate to the pool of water column nitrate in winter. Furthermore, combined measurements of $\delta^{18} \mathrm{O}_{\mathrm{NO} 3}$ and $\delta^{15} \mathrm{~N}_{\mathrm{NO} 3}$ allowed us to better understand water column nitrate cycling in early spring, because the data revealed the influence of both phytoplankton assimilation and nitrification.

\section{MATERIALS AND METHODS}

Sampling. Water samples from the German Bight were taken by a CTD/rosette sampler on 2 RV 'Alkor' cruises (AL 292: 20 to 30 January 2007 and AL 296: 7 to 20 March 2007) and on a field campaign in the open North Sea with RV 'Walther Herwig III' (WH 296: 17 January to 16 February 2007). All 3 expeditions sampled a prescribed grid of stations for environmental monitoring. Water samples were filtered over GF/F filters on board and frozen until analysis. Sampling during AL 292 was mostly restricted to coastal stations due to weather conditions. During AL 292 and AL 296, samples were taken from near-bottom water and from the surface (5 m). During WH 296, deeper water areas in the open North Sea were visited, and 1 additional intermediate depth level (50 or $75 \mathrm{~m}$ ) was sampled on this expedition. Details of sampling stations are shown in Supplement 1 available at www.int-res.com/articles/ suppl/m408p007_supp.pdf.

Analytical methods. Determination of nitrate concentrations: Nitrate concentrations were determined according to Grasshoff \& Anderson (1999) using an automated nutrient analyzer (AA3, Bran+Luebbe). Nitrate was reduced to nitrite by passing over a cadmium reduction column and was subsequently reacted to an azo dye with $\mathrm{N}$-(1-naphtyl) ethylenediamine. This colour complex was determined photometrically at a wavelength of $540 \mathrm{~nm}$. The detection limit for our setup was $0.5 \mu \mathrm{mol} \mathrm{l}^{-1}$.

Isotopic analysis of nitrate in water samples: $\delta^{15} \mathrm{~N}$ and $\delta^{18} \mathrm{O}$ values of nitrate were determined with the denitrifier method (Sigman et al. 2001, Casciotti et al. 2002). Water samples were injected into a suspension of Pseudomonas aureofaciens (ATCC\#13985) for combined analysis of $\delta^{15} \mathrm{~N}$ and $\delta^{18} \mathrm{O}$, or Pseudomonas chlororaphis for $\delta^{15} \mathrm{~N}$ analysis only. $\delta^{15} \mathrm{~N}$ values determined with either strain showed reproducibility within the standard deviation of measurements. Both bacterial strains denitrify nitrate to $\mathrm{N}_{2} \mathrm{O}$ under anoxic conditions, because they lack nitrous oxide reductase activity and cannot produce $\mathrm{N}_{2}$. The $\mathrm{N}_{2} \mathrm{O}$ gas produced is flushed by purging the sample vials with helium, concentrated and purified on a GasBenchII and analyzed on a Delta Plus XP mass spectrometer (ThermoFinnigan). To avoid concentration-dependent fractionation effects, the sample size was adjusted to a final $\mathrm{N}_{2} \mathrm{O}$ amount of $10 \mathrm{nmol}$. For each sample, replicate measurements were performed, and an international standard (IAEA-N3: $\delta^{15} \mathrm{~N} 4.7 \%$; $\delta^{18} \mathrm{O} 25.6 \%$ ) was measured with each batch of samples. (Böhlke et al. 2003). To correct for exchange with oxygen from $\mathrm{H}_{2} \mathrm{O}$ during the conversion to $\mathrm{N}_{2} \mathrm{O}$ we used an ${ }^{18} \mathrm{O}$-enriched water standard and applied the correction proposed by Casciotti et al. (2002). This correction has recently been revised (Sigman et al. 2009), and we applied an additional offset of $-0.6 \%$ o (see Knapp et al. 2008).

The SD for IAEA-N3 was $0.2 \%$ for $\delta^{15} \mathrm{~N}$ and $0.5 \%$ for $\delta^{18} \mathrm{O}(\mathrm{n}=5)$. The SD of replicate analyses was in the same range as for the analyzed standards. For further quality assurance of the results, we measured an internal potassium nitrate standard with each batch of samples. The long-term SD for the internal standard was within the same specification for $\delta^{15} \mathrm{~N}$ and $\delta^{18} \mathrm{O}$ as in IAEA-N3 $(\mathrm{n}=29)$.

Mixing calculations: To assess the mixing pattern of riverine and marine nitrate in the German Bight and to detect internal sources and sinks over the course of the mixing gradient, we applied the conservative mixing equations by Fry (2002). Deviations from the theoretical conservative mixing lines of concentrations or isotope signatures point towards sources and sinks in the mixing gradient (Fig. 2). When net sources and sinks of nutrients are balanced, this can result in a pseudo-conservative mixing line of concentrations. In this case, stable isotope signatures can provide additional insight into nitrate cycling. Their composition will deviate from the conservative mixing lines, if processes reducing nitrate concentrations (assimilation, denitrification) are associated with different fractionation factors, or if sources (nitrification) add nitrate with isotope signatures differing from that of assumed end-members of the mixing equation.

In order to evaluate the mixing characteristics of German Bight waters, the nitrate isotopic composition in samples with the lowest salinity on either cruise (salinities of 27.8 and 28.1 on AL 292 and AL 296, respectively) are used as end-member values for the lowsalinity region of the $\mathrm{CCW}$, which is loosely defined by salinities of $<33$. We stress that these are not truly riverine end-member values: the isotope composition of nitrate in low-salinity waters of the CCW integrates over several discrete sources (different rivers with differing $\delta$-values) and any nitrate processing (assimilation, nitrification) that may have occurred in the lower salinity region. Samples with the lowest salinity are reported in Supplement 1. They were taken in the Elbe estuary and, thus, represent only 1 contribution to the CCW nitrate pool; they are not included in the figures or calcu- 

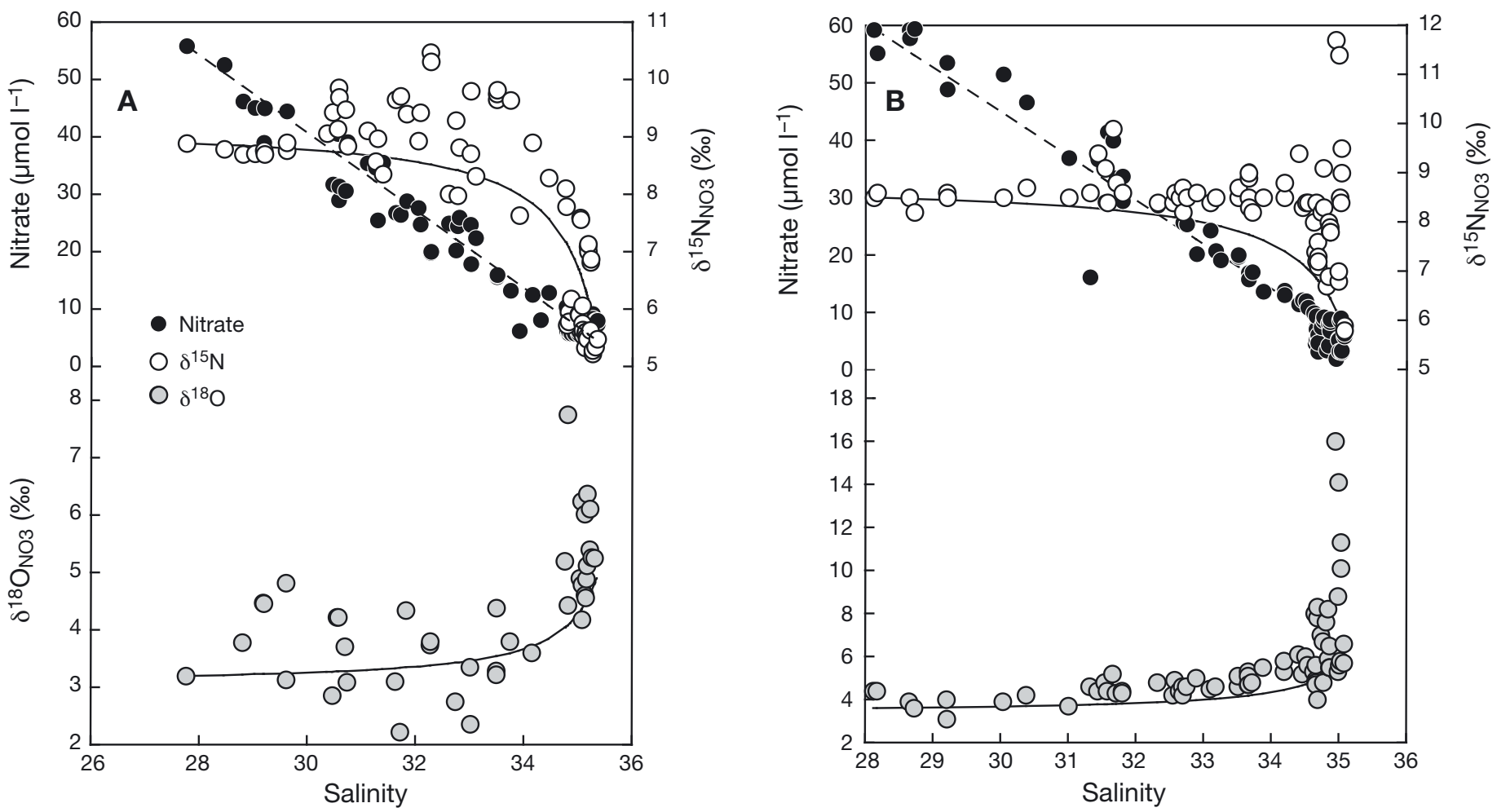

Fig. 2. Nitrate concentrations and isotope values of nitrate plotted versus salinity for (A) January 2007 and (B) March 2007 . Lines indicate calculated conservative mixing. For definitions of end-member values see 'Materials and methods, Analytical methods, Mixing calculations'

lations. The choice of 1 end-member for the low-salinity CCW for each data set, necessary due to a prescribed sampling grid, precludes source attribution to the nitrate loads of individual rivers. Nitrate isotope composition of samples from the open North Sea that were sampled during the WH 296 expedition served as marine end-members.

\section{RESULTS}

The phytoplankton bloom in spring 2007 started late (ICES/EuroGOOS 2007), and both cruises (AL 292 in January and AL 296 in March 2007) sampled water before the onset of significant phytoplankton growth in the central part of the German Bight. The water column was well-mixed and neither nitrate concentrations nor isotope signatures were significantly different in surface and bottom waters. $\delta^{15} \mathrm{~N}_{\mathrm{NO} 3}$ values in high-salinity samples (characteristic of the CNSW with salinity $>34.5$ ) from west of $5^{\circ} \mathrm{E}$ (14 stations with up to 3 depths per station) obtained during WH 296 were $5.6 \pm 0.3 \%$ o $(\mathrm{n}=21)$, whereas $\delta^{15} \mathrm{~N}_{\mathrm{NO} 3}$ in the German Bight ( 8 to $>10 \%$ ) was elevated over the marine background during all sampling campaigns, and highest values invariably occurred in samples from the coastal region with salinities of $<33$ (Figs. $3 \& 4$ ).

\section{January 2007}

The salinity in samples taken in January 2007 ranged from 28 near the Elbe estuary to 35 at offshore stations. Nitrate concentrations decreased from $56 \mu \mathrm{mol}$ $\mathrm{l}^{-1}$ in inshore waters to $<10 \mu \mathrm{mol} \mathrm{l}^{-1}$ in the outer German Bight and were $\sim 6 \mathrm{~mol}^{-1}$ in the open North Sea; nitrate concentrations and salinity are clearly anticorrelated in this sample set $\left(\mathrm{r}^{2}=0.95\right.$, regression line not shown) (Fig. 2A, Supplement 1). $\delta^{15} \mathrm{~N}_{\mathrm{NO} 3}$ values in the German Bight ranged from 5.5\% in offshore waters to $>10 \%$ in coastal waters. In the southern Wadden Sea, $\delta^{15} \mathrm{~N}$ values were between 8 and $9 \%$, which fits the annual means for rivers discharging into this area (Johannsen et al. 2008), whereas $\delta^{15} \mathrm{~N}_{\mathrm{NO}}$ was up to $10 \%$ in the northern Wadden Sea, an area that receives no significant direct river discharges (Fig. 3C). The mixing of nitrate concentrations was mostly conservative, despite some scatter in the salinity range from 30 to 34 (Fig. 2A). Given the limited number of samples from the open North Sea, we attribute the scatter at high salinities to different water masses with slightly varying nitrate concentrations and to the possible impact of denitrification in sediments of the shallow German Bight.

Unlike nitrate concentrations, $\delta^{15} \mathrm{~N}_{\mathrm{NO}}$ values deviate clearly from the theoretical conservative mixing line 

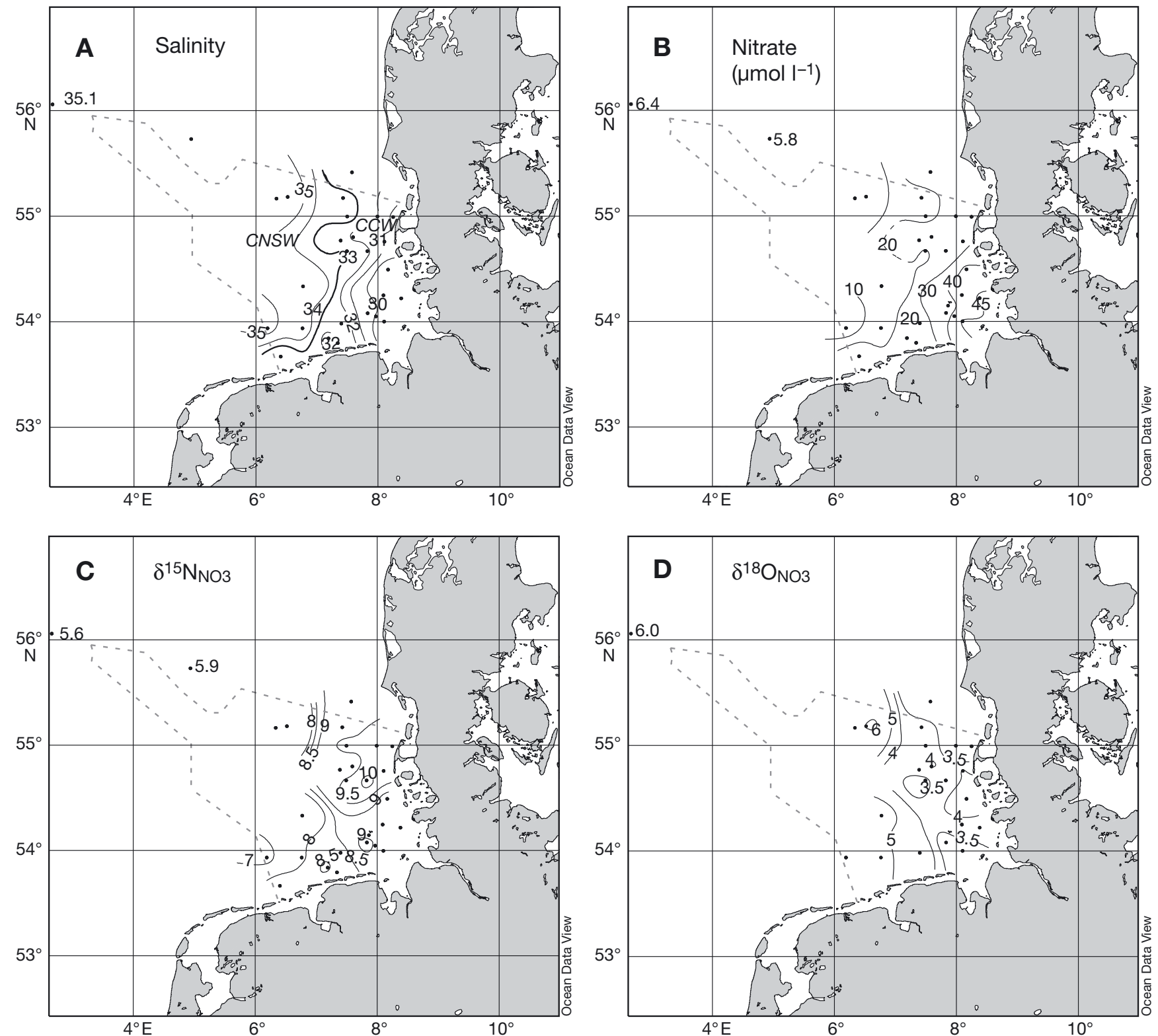

Fig. 3. German Bight. Sampling stations and contours of (A) salinity, (B) nitrate concentration and (C) $\delta^{15} \mathrm{~N}_{\mathrm{NO} 3}$ and (D) $\delta^{18} \mathrm{O}_{\mathrm{NO} 3}$ in the water column during cruises AL 292 and WH 296 in January 2007. Note the broad maximum (>9\%) of $\delta^{15} \mathrm{~N}_{\mathrm{NO}}$ off the North Frisian Islands. Dashed line: German exclusive economic zone (EEZ), routinely monitored by the BSH (Federal Maritime and Hydrographic Agency). Additional samples were taken outside the EEZ during WH 296 and were used to calculate the marine end-member composition

(Fig. 2A). On either end of the salinity scale, $\delta^{15} \mathrm{~N}_{\mathrm{NO}}$ is uniform, and both marine and low-salinity endmember signatures have a distinct isotope value. Samples taken south of the mouth of the Elbe River all plot slightly below the conservative mixing line (the freshwater end-member of which is a mixture of nitrate from different rivers), whereas those that plot above the mixing line $\left(\delta^{15} \mathrm{~N}_{\mathrm{NO} 3}\right.$ values of 9.1 to $10.5 \%$ ) are all situated in the northern Wadden Sea. The spatial pattern is well illustrated in a contour plot of deviations from theoretical conservative mixing for $\delta^{15} \mathrm{~N}_{\mathrm{NO} 3}$ (Fig. 5A) that marks samples near the North Frisian islands, close to the Danish Border, as $>1 \%$ enriched.

$\delta^{18} \mathrm{O}_{\mathrm{NO} 3}$ values are scattered considerably around the theoretical mixing line (Fig. 2A), but a general trend to increasing $\delta^{18} \mathrm{O}_{\mathrm{NO} 3}$ with salinity is visible. In the coastal regions, $\delta^{18} \mathrm{O}_{\mathrm{NO} 3}$ values are 3 to $4 \%$ and rise to $\sim 6 \%$ further offshore, in the open North Sea (Fig. 2A, Supplement 1; not shown in Fig. 3). In the 

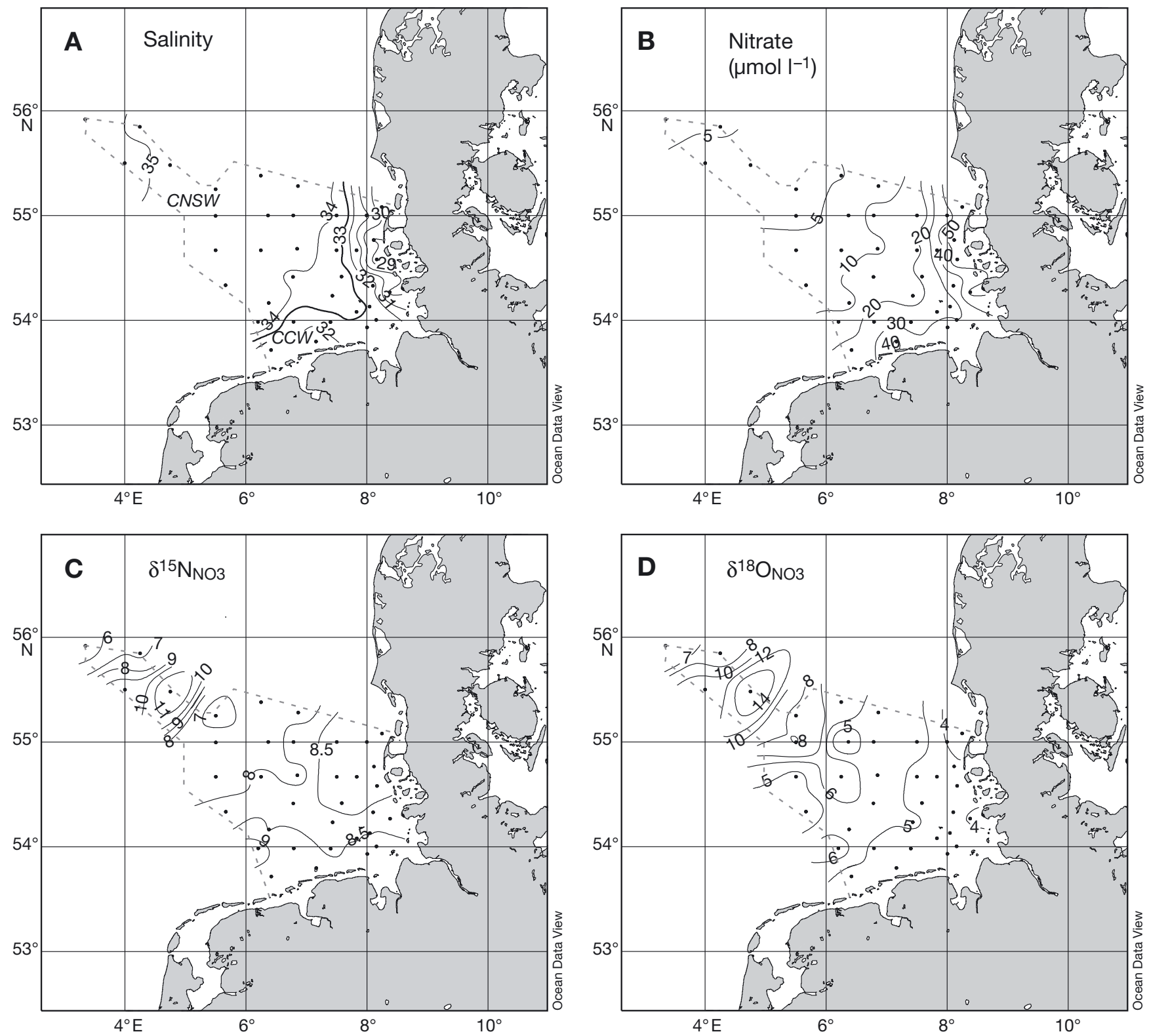

Fig. 4. German Bight. Sampling stations and contour of (A) salinity, (B) nitrate concentration, (C) $\delta^{15} \mathrm{~N}_{\mathrm{NO} 3}$ and (D) $\delta^{18} \mathrm{O}_{\mathrm{NO} 3}$ in the water column in March 2007 (cruise AL 296). Note the maximum for both isotope species in the outer German Bight

German Bight proper, $\delta^{18} \mathrm{O}_{\mathrm{NO} 3}$ values scatter by about $1 \%$ around conservative mixing line, with a tendency to values on or below the conservative mixing line, mostly in the region off North Frisia (Fig. 5B).

\section{March 2007}

In March 2007, the sampling scheme covered waters with salinities from 28.1 in the CCW up to 35 near Dogger Bank. Nitrate concentrations in the lowest salinity samples from the inner CCW were slightly higher than in January, with maximum values of $59 \mu \mathrm{mol} \mathrm{l}^{-1}$ in the northern Wadden Sea (Fig. 4B, Supplement 1), and a minimum concentration of $1.9 \mathrm{umol} \mathrm{l}^{-1}$ in the westernmost samples.

As in January, nitrate concentrations were linearly anti-correlated $\left(\mathrm{r}^{2}=0.93\right)$ to salinity (Fig. $\left.2 \mathrm{~B}\right) \cdot \delta^{15} \mathrm{~N}_{\mathrm{NO}}$ values in March were slightly higher (around $8.5 \%$ ) in the southern Wadden Sea than in the rest of the inner German Bight, and the values generally decreased further offshore (Fig. 4C). The interpretation of isotope mixing behaviour is somewhat more complicated than in January, because $\delta^{15} \mathrm{~N}_{\mathrm{NO}}$ in the high salinity range 

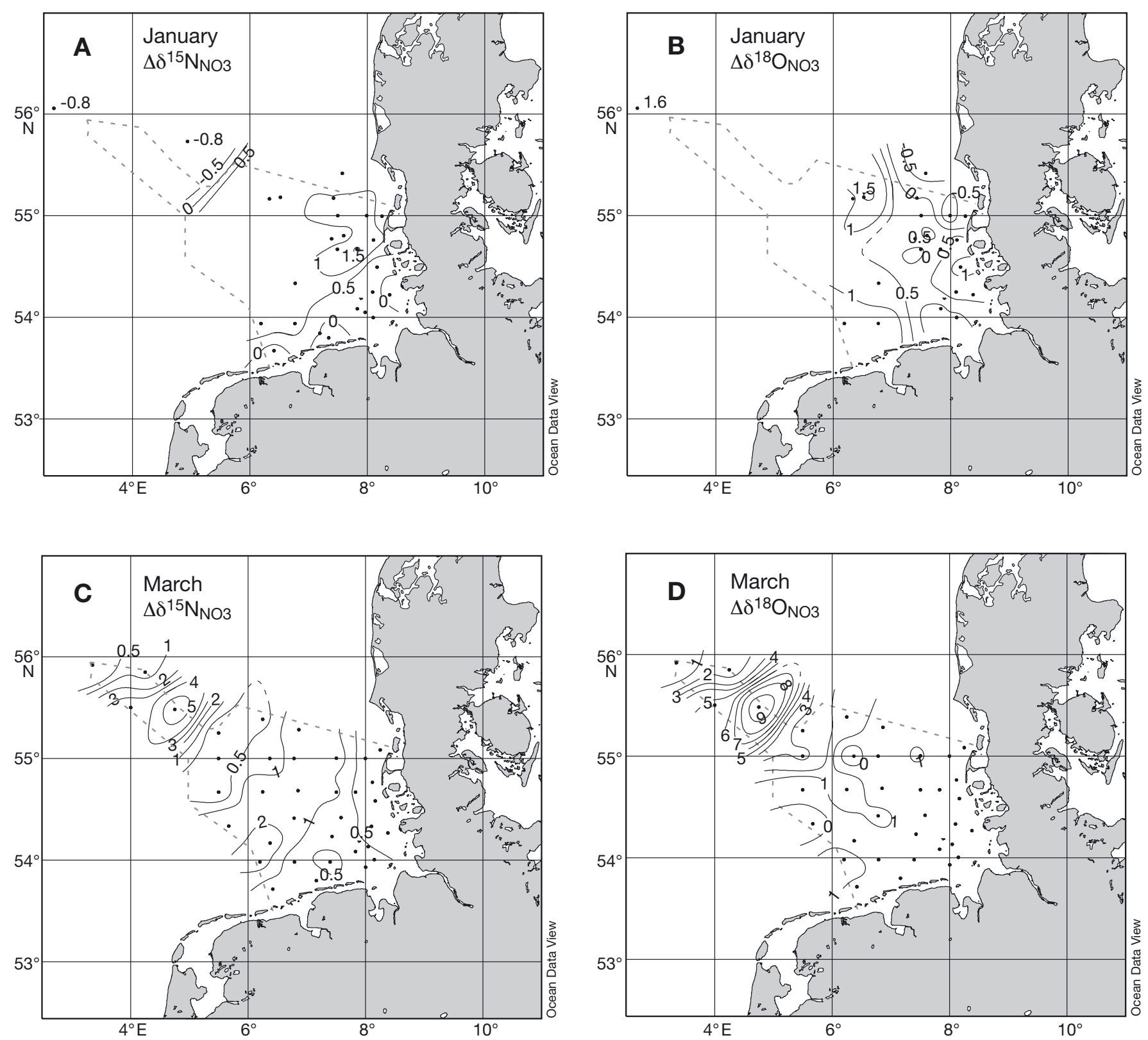

Fig. 5. German Bight. Deviations from theoretical conservative mixing for (A) $\delta^{15} \mathrm{~N}_{\mathrm{NO} 3}$ in January, (B) $\delta^{18} \mathrm{O}_{\mathrm{NO}}$ in January, (C) $\delta^{15} \mathrm{~N}_{\mathrm{NO} 3}$ in March and (D) $\delta^{18} \mathrm{O}_{\mathrm{NO} 3}$ in March, 2007

was variable and did not entirely conform to a conservative mixing pattern (Fig. 2B). Contrary to the overall trend of decreasing $\delta^{15} \mathrm{~N}_{\mathrm{NO} 3}$ with rising salinity, $\delta^{15} \mathrm{~N}_{\mathrm{NO} 3}$ increased up to $11 \%$ for 1 subset of samples in the western part of the study area, decreasing again to marine background values of $\sim 5 \%$ further offshore, in samples with the same salinity values (Fig. $4 \mathrm{C}$ ).

A similar divergence from conservative mixing is seen in $\delta^{18} \mathrm{O}_{\mathrm{NO} 3}$ values at salinities $>34$ (Figs. 2B \& 4D). $\delta^{18} \mathrm{O}_{\mathrm{NO} 3}$ values range from 3 to $5 \%$ in coastal waters, but have no clear trend with rising salinity: one subset of offshore samples near salinities of 35 has a maxi- mum $\delta^{18} \mathrm{O}_{\mathrm{NO} 3}$ of $12 \%$, whereas another subset of offshore samples only shows a very weak increase to $5 \%$ (Figs. 2B \& 4D). Both $\delta^{15} \mathrm{~N}_{\mathrm{NO} 3}$ and $\delta^{18} \mathrm{O}_{\mathrm{NO} 3}$ values rise above the hypothetical conservative mixing line in the same region of the outer German Bight (Fig. 5C,D).

\section{DISCUSSION}

The isotopic composition of water column nitrate in the German Bight is governed by mixing of external inputs - advection of nitrate carried into the bight with 
residual circulation, atmospheric deposition and river input-and internal processes that either consume (assimilation, denitrification) or produce (nitrification) nitrate. All these sources and sinks imprint on the isotopic composition of the nitrate pool. In the following, we examine our data for characteristic fingerprints of external nitrate sources and for anomalies from expected conservative mixing indicative of nitrate assimilation or recycling.

\section{Nitrate mixing patterns in the German Bight}

The coastal water mass of low salinity, high nitrate concentrations and high $\delta^{15} \mathrm{~N}_{\mathrm{NO} 3}$ values that dominates the inner German Bight is clearly impacted by riverine nitrate discharge, which is enriched in ${ }^{15} \mathrm{~N}$ (Kendall 1998, Johannsen et al. 2008). The most important nitrate sources are the Elbe and Weser Rivers (Sündermann 1997), which often dominate over other sources such as the coastal water advected into the bight by the residual counter-clockwise circulation or the Rhine River (Brockmann et al. 1999). Elbe and Weser nitrate is markedly enriched (with annual weighted means of $\delta^{15} \mathrm{~N}_{\mathrm{NO} 3}$ between 8 and $8.5 \%$; Johannsen et al. 2008) and, when entrained in the nitrate pool of the CCW, raises the $\delta^{15} \mathrm{~N}_{\mathrm{NO} 3}$ (Dähnke et al. 2008a).

However, some individual fingerprints can be discerned in the mixed nitrate pool of the CCW: Elbe River nitrate in January is $2 \%$ more enriched in $\delta^{15} \mathrm{~N}$ than that of other rivers discharging into the bight (Johannsen et al. 2008), and its influence shows up in the isotope mixing pattern for the CCW (Fig. 3C). $\delta^{15} \mathrm{~N}_{\mathrm{NO} 3}$ values close to the mouth of the Elbe in the Central Wadden Sea are slightly elevated relative to values in samples further south that are not influenced by Elbe nitrate. Instead, the slightly lower $\delta^{15} \mathrm{~N}_{\mathrm{NO} 3}$ values in the southern Wadden Sea are caused by nitrate loads from the Weser and/or Rhine Rivers. The enriched Elbe nitrate is best indicated by a local maximum of $>10 \%$ in the Elbe estuary (Supplement 1, data not shown in plots).

In March 2007, the $\delta^{15} \mathrm{~N}_{\mathrm{NO} 3}$ values south of the mouth of the Elbe, close to the Weser River, appear to be more enriched than surrounding waters, and comparison to the bimonthly measurements by Johannsen et al. (2008) shows that, in March, the $\delta^{15} \mathrm{~N}_{\mathrm{NO} 3}$ values in the Weser River are elevated by approximately $2 \%$ over those in the Elbe River. Despite its high nitrate load, the Rhine $\delta^{15} \mathrm{~N}_{\mathrm{NO} 3}$ values apparently have little influence on the isotope signature in this mixing region, which coincides with findings from contaminant distribution studies (Sündermann 1997).

A second regional maximum is visible in January in the northern Wadden Sea area near the North Frisian coast, where $\delta^{15} \mathrm{~N}_{\mathrm{NO} 3}$ values rise to a local maximum of $>10 \%$. Unlike the patterns we discussed above, this maximum does not appear to be directly related to river discharge, and it was not observed during the March cruise. In the following, we will address different mechanisms that may explain the different isotopic distributions in the water column in these 2 seasons.

\section{Benthic-pelagic interactions}

There are 2 possible explanations for the maximum values of $\delta^{15} \mathrm{~N}_{\mathrm{NO} 3}$ being along the North Frisian coast in January: (1) the input of additional isotopically enriched nitrogen from landward sources (via groundwater or subtidal estuaries); (2) the interplay of isotope fractionation during biological processes over the course of a seasonal cycle and between water column and sediment N-pools.

Groundwater can contain concentrations of DIN that significantly exceed those found in coastal water bodies, and may thus be significant in regional nutrient budgets. Furthermore, it is known that $\delta^{15} \mathrm{~N}$ in groundwater can be high due to fractionation during denitrification (Amberger \& Schmidt 1987, Kroeger \& Charette 2008). But there is no evidence that nitrate discharge from groundwater plays a significant role in our study area, and the contribution of nitrate by groundwater to the Wadden Sea is dwarfed by riverine inputs of nitrate (Andersen et al. 2006). In the specific region of the northern Wadden Sea, where the maximum $\delta^{15} \mathrm{~N}_{\mathrm{NO} 3}$ values occur, Andersen et al. (2007) found only a small impact of nitrate leaching from groundwater and attributed this to a long nitrate residence time in the aquifers that results in near complete denitrification and in mixing with pre-industrial groundwater masses low in nitrate. Even in intertidal back-barrier basins, freshwater input is only of minor importance (van Beusekom et al. 1999, de Beer et al. 2005). We can thus safely rule out groundwater inputs as a source responsible for the high $\delta^{15} \mathrm{~N}_{\mathrm{NO} 3}$ values observed in the water column north of $54.5^{\circ} \mathrm{N}$.

We favour instead the second explanation that is based on complete assimilation of residual CCW nitrate in the area, occurring regularly in spring and summer, which then leads to production of ${ }^{15} \mathrm{~N}$ enriched particulate nitrogen from an enriched residual nitrate pool and the subsequent remineralisation of this sedimentary particulate nitrogen in winter months.

Generally, the mass-dependent isotopic fractionation during progressive consumption of nitrate by phytoplankton causes an increase in $\delta^{15} \mathrm{~N}_{\mathrm{NO} 3}$ and $\delta^{18} \mathrm{O}_{\mathrm{NO} 3}$ of the remaining nitrate. The extent to which the light isotope is preferred over the heavy one is defined as 
the isotope effect $\varepsilon$ and is dependent on the reaction rate coefficients for the light and heavy isotope species, respectively. Nitrate assimilation by phytoplankton causes equal increases in $\delta^{15} \mathrm{~N}$ and $\delta^{18} \mathrm{O}$ of the residual $\mathrm{NO}_{3}{ }^{-}$(Granger et al. 2004), with fractionation factors for marine phytoplankton ranging from 5 to $20 \%$.

We now want to elucidate how fractionation during nitrate assimilation may, indirectly, be responsible for the high $\delta^{15} \mathrm{~N}_{\mathrm{NO} 3}$ values we find in the northern part of the German Bight in January.

During the biologically active season (spring and early summer) progressive assimilation of water column nitrate, essentially of riverine origin in the CCW, causes a decrease in nitrate concentration as each water parcel moves northwards in the residual current direction. This decrease in nitrate concentration is well-documented by typically low summer nitrate concentrations in the northern Wadden Sea (Brockmann et al. 1999) and nitrate limitation of biological productivity in this part of the Wadden Sea in summer (Loebl et al. 2009). This uptake will lead to increasingly enriched $\delta^{15} \mathrm{~N}_{\mathrm{NO} 3}$ and $\delta^{18} \mathrm{O}_{\mathrm{NO} 3}$ in water column nitrate, and will, when nitrate is completely assimilated, cause isotopic enrichment in phytoplankton. Most of this particulate nitrogen is mineralized and recycled, but a small part $(<1 \%)$ is deposited in sediment (de Haas et al. 2002), where $\delta^{15} \mathrm{~N}$ consequently should be elevated over the surrounding regions. This hypothesis is supported by: (1) the pronounced regional maximum of $\delta^{15} \mathrm{~N}$ in surface sediments that coincides with the area that has elevated $\delta^{15} \mathrm{~N}_{\mathrm{NO}}$ (Dähnke et al. 2008b, Serna et al. in press) and (2) results of experiments with a 3dimensional ecosystem model that tracks $\mathrm{N}$-isotopes in the German Bight (Pätsch et al. 2010). Both suggest that ${ }^{15} \mathrm{~N}$-enriched residual nitrate of the $\mathrm{CCW}$ is regularly transferred as particulate nitrogen to sediments off the coast of North Frisia.

Sediment-water fluxes of reactive nitrogen are high in the northern Wadden Sea and the inner German Bight and support a significant portion of gross primary production (Hydes et al. 1999). Nutrient recycling is intense (e.g. van Beusekom \& de Jonge 2002, Pätsch et al. 2010), and mineralisation of part of the sedimentary particulate nitrogen $\left(\mathrm{NH}_{4}{ }^{+}\right)$in winter is evident from high ammonia concentrations off the coast of North Frisia during winter months (Fig. 6). Exceptionally, high concentrations of suspended particulate matter (Brasse et al. 1999) also indicate intense physical sediment-water interaction and resuspension of sediments. We therefore assume that the sedimentary $\delta^{15} \mathrm{~N}$ signal, via nitrification in the sediments, is transferred to the water column.

The legacy of the spring/summer nitrate assimilation (and its $\delta^{15} \mathrm{~N}_{\mathrm{NO} 3}$ signal), intermittently stored in surface sediments, is likely to influence isotopic composition of the winter nitrate pool after ammonification and nitrification. In contrast to assimilation, the 2 isotopes in nitrate produced by nitrification (oxidation of $\mathrm{NH}_{4}{ }^{+}$to $\mathrm{NO}_{2}{ }^{-}$and $\mathrm{NO}_{3}{ }^{-}$) are uncoupled: for a first approximation, this nitrate inherits the $\delta^{15} \mathrm{~N}$ from particulate nitrogen being mineralised (due to limited diffusion in sediments), whereas the $\delta^{18} \mathrm{O}$ is locked to that of ambient seawater with a positive offset of approximately $2 \%$ (Casciotti et al. 2002, Sigman et al. 2005). Thus, the difference in enrichment of $\delta^{18} \mathrm{O}_{\mathrm{NO} 3}$ versus $\delta^{15} \mathrm{~N}_{\mathrm{NO} 3}$ corroborates the assumption of significant nitrification (Fig. 5A,B).

The obvious enrichment in $\delta^{15} \mathrm{~N}_{\mathrm{NO} 3}$ cannot be attributed to an effect of progressive assimilation (which is unlikely considering the season), because the 2 nitrate isotope pairs are clearly uncoupled, which is a strong indication for the presence of recycled nitrate (via nitrification) in the winter nitrate pool off North Frisia. By March, the nearshore region showed no significant deviations from conservative mixing of nitrate isotopes (Fig. 5C,D); at this time, anomalies are seen in the offshore area.

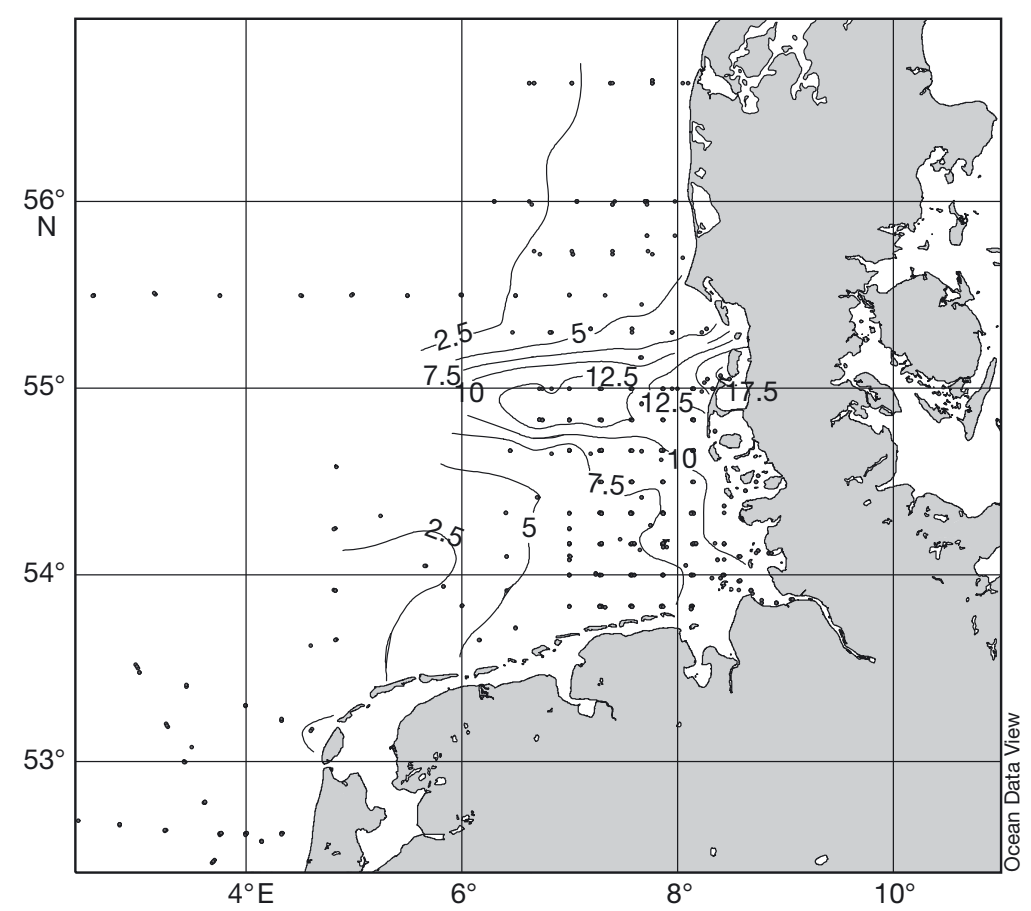

Fig. 6. German Bight. Ammonium concentrations $\left(\mu m o l l^{-1}\right)$ in water below $5 \mathrm{~m}$, pooled from November to January. Data used for this figure are compiled in the NOWESP data base (Radach et al. 1996) 


\section{Water column nitrate turnover in the German Bight?}

Contours of $\delta^{15} \mathrm{~N}_{\mathrm{NO} 3}$ and $\delta^{18} \mathrm{O}_{\mathrm{NO} 3}$ (Fig. $4 \mathrm{C}, \mathrm{D}$ ) of samples taken in March 2007 (expedition AL 296) outline high $\delta$-values at 2 stations in the outer the German Bight, which are significantly higher than expected from conservative mixing (Fig. 5C,D) and in which the $\delta^{18} \mathrm{O}_{\mathrm{NO} 3}$ enrichment exceeds the enrichment in $\delta^{15} \mathrm{~N}_{\mathrm{NO}}$. Salinity is $>34.5$, marking this as CNSW, and nitrate concentrations are $<6 \mu \mathrm{mol} \mathrm{l^{-1 }}$. Riverine input can thus be neglected. Although our data are limited due to the coarse sampling grid, we infer a contribution of recycled nitrate from nitrification, which may be held responsible for the increase and the uncoupling of the 2 isotope pairs in these samples.

To illustrate our reasoning, we plotted $\delta^{18} \mathrm{O}_{\mathrm{NO} 3}$ versus $\delta^{15} \mathrm{~N}_{\mathrm{NO} 3}$ for samples taken on all 3 cruises in January to March 2007 (Fig. 7). Those samples taken in January in the open North Sea on WH 296 have an average $\delta^{15} \mathrm{~N}$ value of $5.7 \%$ and a $\delta^{18} \mathrm{O}$ value of $5 \%$ (cf. Supplement 1) and are taken to represent the marine nitrate prior to processing in the German Bight. We point out that the $\delta^{18} \mathrm{O}_{\mathrm{NO} 3}$ value determined in our end-member samples is higher than that of deepocean nitrate (approximately $2 \%$; Sigman et al. 2009) or of sub-thermocline nitrate in the NE Atlantic $(2.4 \%$; Bourbonnais et al. 2009), but we currently have no good explanation for this deviation.

Two distinct trends originate from this source signature (Fig. 7). The majority of data points scatters around a slight trend to higher $\delta^{15} \mathrm{~N}_{\mathrm{NO} 3}$ and lower $\delta^{18} \mathrm{O}_{\mathrm{NO} O}$ i these samples are from coastal regions and are likely dominated by nitrate from rivers or possibly sediment nitrification in coastal regions. Much of the scatter around this mixing trend is caused by samples taken in March (AL 296), and we attribute it to the onset of major biological activity (such as assimilation in the water column) that leads to an enrichment of $\delta^{18} \mathrm{O}$ and $\delta^{15} \mathrm{~N}$ in nitrate, thus driving the $\mathrm{NO}_{3}{ }^{-}$signature away from this trend. A second group of samples outlines another distinct trend of rising $\delta^{18} \mathrm{O}_{\mathrm{NO} 3}$ and $\delta^{15} \mathrm{~N}_{\mathrm{NO} O 3}$, following a slope of 1.6:1 (Fig. 7). These samples were taken in March 2007 and deviate clearly from the conservative mixing line we calculated according to Fry et al. (2002) (Figs. 2B \& 5) and originate from the vicinity of the Dogger Bank, a shallow region at the edge of our study area. While there was no apparent phytoplankton bloom in the inner German Bight in March 2007, the bloom was incipient specifically in this Dogger Bank region, where winter blooms are known to be common (ICES/EuroGOOS 2007, Brockmann \& Topcu 2002). This supports the role of phytoplankton assimilation in raising the dual isotope values of nitrate. The slope of the enrichment trend also points to other processes besides assimilation,

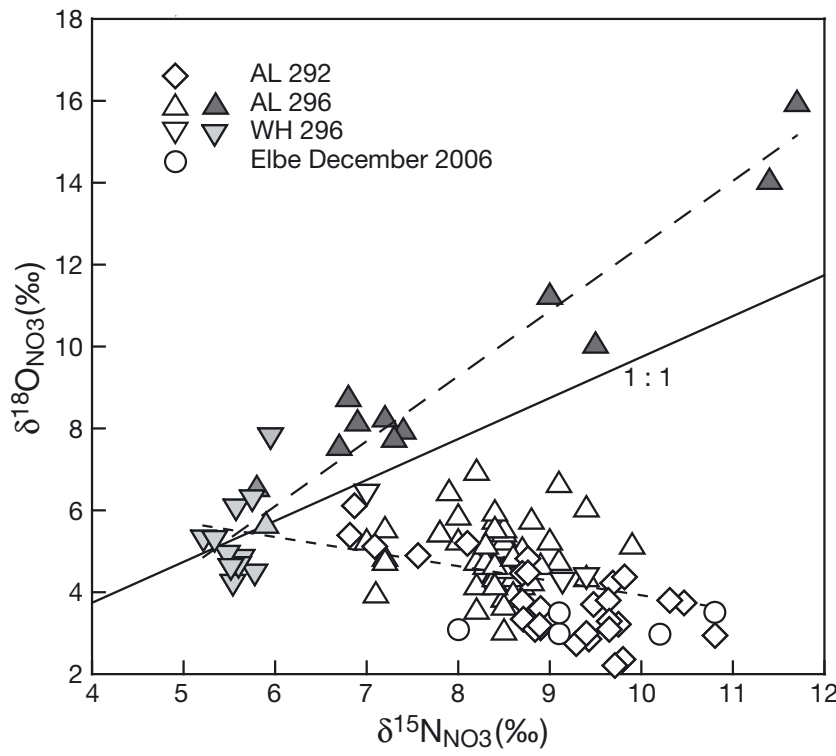

Fig. 7. Plot of $\delta^{18} \mathrm{O}_{\mathrm{NO} 3}$ versus $\delta^{15} \mathrm{~N}_{\mathrm{NO} 3}$. Data for the Elbe River are from Dähnke et al. (2008a). Dashed lines: trends that are attributed to mixing or biological activity. Light grey shading indicates the marine source signature for the trends attributed to biological activity (dark grey) or riverine mixing (white)

because the uptake of nitrate by phytoplankton is known to result in a parallel increase of both stable isotopes on a slope of 1:1 (Granger et al. 2004). The slope of 1.6:1 thus indicates that either ${ }^{18} \mathrm{O}$-enriched nitrate has been added to the residual nitrate pool, or that an additional input of ${ }^{15} \mathrm{~N}$-depleted nitrate shifted the $\delta^{15} \mathrm{~N}$ of water column nitrate away from the assimilation-related 1:1 co-enrichment line.

We calculated the apparent fractionation factors ${ }^{15} \varepsilon$ and ${ }^{18} \varepsilon$ that are associated with the nitrate drawdown in the subset of samples following the 1.6:1 enrichment trend according to Mariotti et al. (1981). Assuming a marine source signature, as we find in deep waters of the open North Sea (Supplement 1), ${ }^{15} \varepsilon=3.9 \pm 0.9 \%$ and ${ }^{18} \varepsilon=6.2 \pm 1.2 \%$ (95\% CI). Notably, ${ }^{15} \varepsilon$ is at the low end of the range of fractionation factors previously reported for assimilation by marine phytoplankton (Granger et al. 2004), providing additional evidence for input of isotopically light nitrogen to the nitrate pool. The main clue, though, appears to lie in the marked difference in isotope effects for $\delta^{18} \mathrm{O}_{\mathrm{NO} 3}$ and $\delta^{15} \mathrm{~N}_{\mathrm{NO} 3}$.

Atmospheric input of $\mathrm{NO}_{\mathrm{X}}$ with low $\delta^{15} \mathrm{~N}$. Would explain the deviation from a 1:1 change. However, we discard this possibility, because there was no significant rainfall before or during the time of sampling, and there is no clear difference between surface and deeper water samples to suggest any recent input large enough to significantly alter the isotope signature. Given the spatial limitation, the proximity of Dogger Bank and the co-occurrence of elevated 
$\delta^{15} \mathrm{~N}_{\mathrm{NO} 3}$ and $\delta^{18} \mathrm{O}_{\mathrm{NO} 3}$ values, it appears more plausible that a biological turnover process besides phytoplankton assimilation is responsible for this difference in apparent fractionation factors.

Different processes have the potential to change either of the 2 isotopes in nitrate. Sigman et al. (2005) found a similar deviation of a 1:1 slope in deep waters off the coast of Baja California. They attributed it to nitrite/nitrate redox cycling during denitrification, which has an effect on $\delta^{18} \mathrm{O}_{\mathrm{NO} 3}$ only, while the $\delta^{15} \mathrm{~N}_{\mathrm{NO} 3}$ signature remains unchanged. This process should, however, not occur in a well-oxygenated, mixed water column such as that in the German Bight at this time of year. The same applies for the input of depleted nitrate via mineralisation of recently fixed $\mathrm{N}_{2}$ - there is no empirical evidence for $\mathrm{N}_{2}$ fixation occurring at significant levels in the German Bight at any time of year (Brion et al. 2004), much less in winter.

This again, as in the of North Frisian sediments in winter, leaves nitrification as a likely internal source of nitrate for consideration, in which the original $\delta^{15} \mathrm{~N}_{\mathrm{NO} 3} / \delta^{18} \mathrm{O}_{\mathrm{NO} 3}$ ratio of the water column nitrate pool is differentially modified (Wankel et al. 2007). Thus, our findings can be explained if the commencing bloom in the outer German Bight is associated with nitrate assimilation that raises $\delta^{15} \mathrm{~N}_{\mathrm{NO} 3}$ and $\delta^{18} \mathrm{O}_{\mathrm{NO} 3}$ equally, whereas the steeper enrichment trend at stations near Dogger Bank results from the simultaneous occurrence of nitrification (Wankel et al. 2007). In the North Sea and its estuaries, nitrification has been shown to occur perennially and regardless of water temperature (Wuchter et al. 2006, Brion et al. 2008). Especially in winter, nitrifying Archaea are abundant in the particle-rich water column of the southern North Sea (Wuchter et al. 2006), and cell counts for this group peak in winter (Herfort et al. 2007). We do not have any direct evidence for the participation of Archaea, but the active nitrification despite low water temperatures adds evidence for an archaeal contribution to nitrification. Regardless of the microbiological players, the anomalous nitrate isotopic composition in the water column in spring is consistent with the role of nitrification in the nitrogen cycle of the German Bight.

\section{CONCLUSIONS}

The nitrate isotope data acquired in the German Bight in January and March make it possible to discern different processes that affect water column nitrate inventories. In the area closest to the coast, we see evidence for varying influences of riverine nitrate and particulate matter remineralisation. Apparently, nitrate deriving from mineralisation and nitrification of sedimentary organic matter can be equally important in maintaining nitrate levels in the northern German Bight as riverine inputs from the Rhine or Elbe.

In regions further offshore, with the onset of biological activity in March 2007, the dual isotope signatures of nitrate show that nitrate is consumed rapidly by biological processing. Additionally, the isotope signatures suggest that a portion of the extant nitrate derives from nitrification. Together, the data indicate that recycled nitrate contributes significantly to total nitrate in the German Bight, a notion that has until now only been inferred on the basis of mass balances.

Acknowledgements. We thank S. Weigelt-Krenz from the Federal Maritime and Hydrographic Agency and G. Wegner from the Federal Research Centre for Fisheries for offering us the possibility to obtain samples from the 3 cruises. We also thank the participants of the 'Alkor' and 'Walther Herwig III' cruises for sample collection on the vessel. Three anonymous reviews are acknowledged who helped us greatly. Part of this work was funded by the German Research Foundation.

\section{LITERATURE CITED}

Amberger A, Schmidt HL (1987) The natural isotope content of nitrate as an indicator of its origin. Geochim Cosmochim Acta 51:2699-2705

Andersen MS, Postma D, Jakobsen R, Baron L, Chapellier D, Gregersen J (2006) Mapping groundwater discharge and assessing the attenuation of groundwater nitrate at a site in the Wadden Sea. In: Laursen K (ed) Monitoring and assessment in the Wadden Sea. Proceedings from the 11th scientific Wadden Sea symposium. National Environmental Research Institute, Roskilde, p 73-81

Andersen MS, Baron L, Gudbjerg J, Gregersen J, Chapellier D, Jakobsen R, Postma D (2007) Discharge of nitratecontaining groundwater into a coastal marine environment. J Hydrol (Amst) 336:98-114

Beddig S, Brockmann U, Dannecker W, Korner D and others (1997) Nitrogen fluxes in the German Bight. Mar Pollut Bull 34:382-394

Böhlke JK, Mroczkowski SJ, Coplen TB (2003) Oxygen isotopes in nitrate: new reference materials for ${ }^{18} \mathrm{O}:{ }^{17} \mathrm{O}:{ }^{16} \mathrm{O}$ measurements and observations on nitrate-water equilibration. Rapid Commun Mass Spectrom 17:1835-1846

Bourbonnais A, Lehmann MF, Waniek JJ, Schulz-Bull DE (2009) Nitrate isotope anomalies reflect $\mathrm{N}_{2}$ fixation in the Azores Front region (subtropical NE Atlantic). J Geophys Res C 114, C03003, doi: 10.1029/2007JC004617

> Brasse S, Reimer A, Seifert R, Michaelis W (1999) The influence of intertidal mudflats on the dissolved inorganic carbon and total alkalinity distribution in the German Bight, southeastern North Sea. J Sea Res 42:93-103

> Brion N, Baeyens W, De Galan S, Elskens M, Laane R (2004) The North Sea: source or sink for nitrogen and phosphorus to the Atlantic Ocean? Biogeochemistry 68:277-296

Brion N, Andersson MGI, Elskens M, Diaconu C, Baeyens W, Dehairs F, Middelburg JJ (2008) Nitrogen cycling, retention and export in a eutrophic temperate macrotidal estuary. Mar Ecol Prog Ser 357:87-99

Brockmann U, Topcu D (2002) Nutrient atlas of the central and northern North Sea. Umweltbundesamt, Berlin

Brockmann U, Raabe T, Hesse K, Viehweger K and others (1999) Seasonal budgets of the nutrient elements N and P at the surface of the German Bight during winter 1996, spring 1995, and summer 1994. Ocean Dyn 51:267-291 
Casciotti KL, Sigman DM, Hastings MG, Bohlke JK, Hilkert A (2002) Measurement of the oxygen isotopic composition of nitrate in seawater and freshwater using the denitrifier method. Anal Chem 74:4905-4912

- Cloern JE (2001) Our evolving conceptual model of the coastal eutrophication problem. Mar Ecol Prog Ser 210: 223-253

Dähnke K, Bahlmann E, Emeis K (2008a) Nitrogen cycling in the Elbe estuary - assessment by stable nitrate isotopes. Limnol Oceanogr 53:1504-1511

> Dähnke K, Serna A, Blanz T, Emeis KC (2008b) Sub-recent nitrogen-isotope trends in sediments from Skagerrak (North Sea) and Kattegat: changes in N-budgets and N-sources? Mar Geol 253:92-98

de Beer D, Wenzhofer F, Ferdelman TG, Boehme SE and others (2005) Transport and mineralization rates in North Sea sandy intertidal sediments, Sylt-Rømø Basin, Wadden Sea. Limnol Oceanogr 50:113-127

de Haas H, van Weering TCE, de Stigter H (2002) Organic carbon in shelf seas: sinks or sources, processes and products. Cont Shelf Res 22:691-717

Freyer HD (1991) Seasonal-variation of ${ }^{15} \mathrm{~N} /{ }^{14} \mathrm{~N}$ ratios in atmospheric nitrate species. Tellus B Chem Phys Meterol 43:30-44

Fry B (2002) Conservative mixing of stable isotopes across estuarine salinity gradients: a conceptual framework for monitoring watershed influences on downstream fisheries production. Estuaries 25:264-271

Granger J, Sigman DM, Needoba JA, Harrison PJ (2004) Coupled nitrogen and oxygen isotope fractionation of nitrate during assimilation by cultures of marine phytoplankton. Limnol Oceanogr 49:1763-1773

Grasshoff K, Anderson LG (1999) Methods of seawater analysis. Wiley- $\mathrm{VCH}$, London

Herfort L, Schouten S, Abbas B, Veldhuis MJW and others (2007) Variations in spatial and temporal distribution of Archaea in the North Sea in relation to environmental variables. FEMS Microbiol Ecol 62:242-257

> Hydes DJ, Kelly-Gerreyn BA, Le Gall AC, Proctor R (1999) The balance of supply of nutrients and demands of biological production and denitrification in a temperate latitude shelf sea-a treatment of the southern North Sea as an extended estuary. Mar Chem 68:117-131

ICES/EuroGOOS (International Council for Exploration of the Sea, European Global Ocean Observing System) (2007) Update report on North Sea conditions-2nd quarter 2007. ICES/EuroGOOS, Bergen

> Johannsen A, Dähnke K, Emeis K (2008) Isotopic composition of nitrate in five German rivers discharging into the North Sea. Org Geochem 39:1678-1689

Kendall C (1998) Tracing nitrogen sources and cycling in catchments. In: Kendall C, McDonnell JJ (eds) Isotope tracers in catchment hydrology. Elsevier, Amsterdam, p 521-576

Knapp AN, DiFiore PJ, Deutsch C, Sigman DM, Lipschultz F (2008) Nitrate isotopic composition between Bermuda and Puerto Rico: implications for $\mathrm{N}^{2}$ fixation in the Atlantic Ocean. Global Biogeochem Cycles 22:GB3014, doi: 10. 1029/2007GB003107

Kroeger KD, Charette MA (2008) Nitrogen biogeochemistry of submarine groundwater discharge. Limnol Oceanogr 53:1025-1039

> Loebl M, Colijn F, van Beusekom JEE, Baretta-Bekker JG and others (2009) Recent patterns in potential phytoplankton limitation along the Northwest European continental coast. J Sea Res 61:34-43

Lohse L, Malschaert JFP, Slomp CP, Helder W, Vanraaphorst W (1993) Nitrogen cycling in North Sea sediments: interaction of denitrification and nitrification in offshore and

Editorial responsibility: Ronald Kiene,

Mobile, Alabama, USA coastal areas. Mar Ecol Prog Ser 101:283-296

Mariotti A, Germon JC, Hubert P, Kaiser P, Letolle R, Tardieux A, Tardieux P (1981) Experimental determination of nitrogen kinetic isotope fractionation: some principles; illustration for the denitrification and nitrification processes. Plant Soil 62:413-430

> Pätsch J, Serna A, Dähnke K, Schlarbaum T, Johannsen A, Emeis KC (2010) Nitrogen cycling in the German Bight of the SE North Sea - clues from modelling stable nitrogen isotopes. Cont Shelf Res 30:203-213

Radach G, Pätsch J (2007) Variability of continental riverine freshwater and nutrient inputs into the North Sea for the years 1977-2000 and its consequences for the assessment of eutrophication. Estuaries Coasts 30:66-81

Radach G, Gekeler J, Becker G, Bot P and others (1996) The NOWESP research data base. Dtsch Hydrogr Z 48: 241-259

Richardson K, Visser AW, Pedersen FB (2000) Subsurface phytoplankton blooms fuel pelagic production in the North Sea. J Plankton Res 22:1663-1671

Serna A, Pätsch J, Dähnke K, Wiesner MG and others (in press) History of anthropogenic nitrogen input to the German Bight/SE North Sea as reflected by nitrogen isotopes in surface sediments, sediment cores and hindcast models. Cont Shelf Res

Sigman DM, Casciotti KL, Andreani M, Barford C, Galanter M, Bohlke JK (2001) A bacterial method for the nitrogen isotopic analysis of nitrate in seawater and freshwater. Anal Chem 73:4145-4153

Sigman DM, Granger J, DiFiore PJ, Lehmann MM, Ho R, Cane G, van Geen A (2005) Coupled nitrogen and oxygen isotope measurements of nitrate along the eastern North Pacific margin. Global Biogeochem Cycles 19, GB4022, doi: 10.1029/2005GB002458

Sigman DM, DiFiore PJ, Hain MP, Deutsch C and others (2009) The dual isotopes of deep nitrate as a constraint on the cycle and budget of oceanic fixed nitrogen. Deep-Sea Res I 56:1419-1439

Soetaert K, Middelburg JJ (2009) Modeling eutrophication and oligotrophication of shallow-water marine systems: the importance of sediments under stratified and wellmixed conditions. Hydrobiologia 629:239-254

Sündermann J (1997) The PRISMA project: an investigation of processes controlling contaminant fluxes in the German Bight. Mar Ecol Prog Ser 156:239-243

van Beusekom JEE (2005) A historic perspective on Wadden Sea eutrophication. Helgol Mar Res 59:45-54

van Beusekom JEE, de Jonge VN (2002) Long-term changes in Wadden Sea nutrient cycles: importance of organic matter import from the North Sea. Hydrobiologia 475-476: 185-194

van Beusekom J, Brockmann U, Hesse K, Hickel W, Poremba K, Tillmann U (1999) The importance of sediments in the transformation and turnover of nutrients and organic matter in the Wadden Sea and German Bight. Ocean Dyn 51:245-266

Wankel SD, Kendall C, Francis CA, Paytan A (2006) Nitrogen sources and cycling in the San Francisco Bay Estuary: a nitrate dual isotopic composition approach. Limnol Oceanogr 51:1654-1664

- Wankel SD, Kendall C, Pennington JT, Chavez FP, Paytan A (2007) Nitrification in the euphotic zone as evidenced by nitrate dual isotopic composition: observations from Monterey Bay, California. Global Biogeochem Cycles 21, GB 2009, doi: 10.1029/2006GB002723

Wuchter C, Abbas B, Coolen MJL, Herfort L and others (2006) Archaeal nitrification in the ocean. Proc Natl Acad Sci USA 103:12317-12322

Submitted: March 31, 2009; Accepted: February 24, 2010

Proofs received from author(s): May 21, 2010 